\title{
Hypertensive emergency and hypertensive urgency management in the emergency department
}

\section{Acil serviste hipertansif emergency ve hipertansif ivedi durum yönetimi}

\author{
Erhan Arikan
}

Department of Emergency Medicine, Bilecik Education and Training Hospital, Bilecik, Turkey

Corresponding author: Erhan Arkan, MD., Department of Emergency Medicine, Bilecik Education and Training Hospital, Bilecik, Turkey

E-mail: dr.erhan.arikan@gmail.com

Received/Accepted: July 06, 2021 / August 20, 2021

Conflict of interest: There is not a conflict of interest.

\begin{abstract}
SUMMARY
Hypertension (HT) is a serious public health problem with an increasing prevalence all over the world. It is a significant cause of mortality and morbidity due to the complications it causes in the short and long term. The majority of applications to emergency departments are due to HT. Hypertensive crisis is defined as systolic blood pressure $\geq 180 \mathrm{mmHg}$ and/or diastolic blood pressure $\geq 120 \mathrm{mmHg}$. It is evaluated under two separate headings according to the presence of target organ damage (TOD) accompanying these values. If TOD accompanies, it is defined as hypertensive emergency; if TOD is not present, it is defined as hypertensive urgency. Whether or not there is end-organ damage is the most important key point in the management of treatment. In hypertensive emergencies, treatment should be rapid to prevent target organ damage. For this purpose, emergency intravenous treatment should be applied, and the patient should be followed up under intensive care conditions for close hemodynamic follow-up. It has been shown that rapid blood pressure reduction in hypertensive urgency does not contribute to mortality and morbidity in the short term. In fact, it is not recommended because it is known that sudden lowering of blood pressure may cause hypoperfusion. For this purpose, oral antihypertensives are administered for treatment in hypertensive urgency and it is aimed to reach the target blood pressure values within days.
\end{abstract}

Keywords: Hypertensive emergency, hypertensive urgency, hypertensive crisis, emergency department

\section{ÖZET}

Hipertansiyon (HT) tüm dünyada sıklığ1 giderek artan ciddi bir halk sağlığ1 sorunudur. Kısa ve uzun vadede yol açtığ komplikasyonlar nedeniyle önemli bir mortalite ve morbidite nedenidir. Acil servislere başvuruların çoğu HT nedeniyledir. Hipertansif kriz, sistolik kan basıncının $\geq 180 \mathrm{mmHg}$ ve/veya diyastolik kan basıncının $\geq 120 \mathrm{mmHg}$ olması olarak tanımlanır. Bu değerlere eşlik eden hedef organ hasarı (TOD) varlığına göre iki ayrı başlık altında değerlendirilir. TOD eşlik ediyorsa hipertansif acil olarak tanımlanır; TOD yoksa hipertansif ivedi durum olarak tanımlanır. Tedavinin yönetiminde en önemli nokta uç organ hasarının olup olmadığıdır. Hipertansif acil durumlarda, hedef organ hasarını önlemek için tedavi hızlı olmalıdır. Bu amaçla acil intravenöz tedavi uygulanmalı ve hasta yakın hemodinamik takip için 
yoğun bakım koşullarında izlenmelidir. Hipertansif ivedi durumda hızlı kan basıncının düşmesinin kısa vadede mortalite ve morbiditeye katkıda bulunmadığı gösterilmiştir. Aslında kan basıncının ani düşmesinin hipoperfüzyona neden olabileceği bilindiği için önerilmemektedir. Bu amaçla hipertansif ivedi durumda tedavi için oral antihipertansifler uygulanmakta ve günler içinde hedeflenen kan basıncı değerlerine ulaşılması hedeflenmektedir.

Anahtar sözcükler: Hipertansiyon, hipertansif kriz, hipertansif acil, hipertansif ivedi durum, acil servis

\section{INTRODUCTION}

Hypertension (HT) is a serious public health problem with an increasing frequency worldwide ${ }^{1}$. The main reasons for this are the increase in the elderly population, sedentary lifestyle, and irregular and unhealthy diet ${ }^{2}$. Although it is a significant risk factor for many chronic diseases, it is also one of the leading causes of mortality. It has a substantial relationship with short-term and longterm mortality and morbidity ${ }^{3}$. The impacts of HT regularly transform into hypertensive emergencies that can influence various organ frameworks exclusively or all the while. Current HT guidelines classify hypertensive crises as hypertensive emergency and hypertensive urgency. This is important because the treatment approach is different when regulating blood pressure. Today, HT has become an important reason for admissions to emergency services. In a study conducted across Europe, it was reported that HT is the reason for $47.2 \%$ of entries to the emergency department ${ }^{4}$. It is essential to evaluate and properly manage a clinical situation that is such a frequent reason for admission to the emergency department. In particular, hypertensive emergencies are lifethreatening as they cause acute target organ damage (TOD). Therefore, hypertensive emergency is a situation that requires excellent attention from those working in the emergency department. In this review, the management of hypertensive emergency and urgency in the emergency department will be discussed.

\section{Definition}

Hypertension is identified as office systolic blood pressure $(\mathrm{SBP}) \geq 140 \mathrm{mmHg}$ and/or diastolic BP (DBP) values $\geq 90 \mathrm{mmHg}$ (5). Hypertensive crises are divided into two main groups as emergency and urgency. In both clinical conditions, systolic blood pressure is greater than $180 \mathrm{mmHg}$ and diastolic blood pressure is greater than $120 \mathrm{~mm} \mathrm{Hg}$, but they are distinguished by the absence or presence of end-organ damage ${ }^{5}$. End-organ damage typically manifests with dysfunction in the cardiovascular, renovascular, cerebrovascular, or pulmonary systems. Therefore, organ dysfunction is the most critical factor determining the speed and form of treatment necessary in a hypertensive crisis.

Hypertensive urgency is a condition described by acute elevation of blood pressure in the absence of end-organ damage. A hypertensive emergency is a situation in which the aforementioned blood pressure values are equally high but accompanied by signs of end-organ damage (Table 1).

Table 1: Systems and clinical manifestations in which end-organ damage may occur

\begin{tabular}{|c|c|}
\hline Target organ damage & A clinical condition that may occur \\
\hline Heart & $\begin{array}{l}\text { Acute coronary syndrome, pulmonary edema, } \\
\text { acute congestive heart failure, }\end{array}$ \\
\hline Vessels & $\begin{array}{l}\text { Acute aortic dissection, microangiopathic } \\
\text { hemolytic anemia }\end{array}$ \\
\hline Brain & $\begin{array}{l}\text { Transient ischemic attack, seizure, intracerebral } \\
\text { or subarachnoid hemorrhage, cerebral } \\
\text { infarction, hypertensive encephalopathy, } \\
\text { posterior reversible leukoencephalopathy }\end{array}$ \\
\hline Kidney & Acute kidney injury \\
\hline Retina & Papilledema, retinal edema, hemorrhages, \\
\hline Uterus & Pre-eclampsia, Eclampsia \\
\hline
\end{tabular}




\section{Pathology}

The reasons that lead to severe and rapid blood pressure elevation that cause hypertensive emergency and hypertensive emergency are not yet fully understood. However, acute elevations in blood pressure are generally thought to be caused by humoral vasoconstriction and inadequate normal autoregulation resulting from a sudden rise in systemic vascular resistance. This sudden increase in systemic vascular resistance increases the mechanical stress on the vascular wall, causing endothelial damage and increased vascular permeability. This vascular damage causes activation of platelets and coagulation cascades, deposition of fibrin, induction of oxidative stress, and release of inflammatory cytokines. In addition, fibrinoid necrosis, a characteristic vascular lesion of tissue ischemia in small arteries and arterioles, occurs. These cascades and events increase the release of vasoactive substances, causing tissue ischemia, aggravating of hypertension, and deterioration in the patient's clinic ${ }^{6-8}$. Conditions causing hypertensive crisis are shown in Table 2.

Table 2: Conditions causing hypertensive crisis are;

\begin{tabular}{|l|l|}
\hline Essential hypertension & \\
\hline Endocrinological disorders & $\begin{array}{l}\text { Cushing syndrome, primary hyperaldosteronism, } \\
\text { pheochromocytoma, renin-secreting tumors }\end{array}$ \\
\hline Renovascular disease & $\begin{array}{l}\text { Renal artery stenosis, Takayasu arteritis, } \\
\text { Polyarteritis nodosa (PAN) }\end{array}$ \\
\hline Central nervous system & $\begin{array}{l}\text { Brain tumors, cerebral edema and hemorrhage, } \\
\text { spinal cord injury }\end{array}$ \\
\hline Drugs & $\begin{array}{l}\text { Cocaine, amphetamines, tyramine reaction with } \\
\text { the use of monoamine oxidase inhibitors, } \\
\text { antihypertensive medication withdrawal, } \\
\text { phencyclidine, sympathomimetics, lead } \\
\text { intoxication, selective serotonin reuptake } \\
\text { inhibitor (SSRI) use }\end{array}$ \\
\hline Coarctation of the aorta & \begin{tabular}{l} 
Burns, Pain \\
\hline
\end{tabular} \\
\hline
\end{tabular}

\section{Initial Evaluation}

Initial diagnostic evaluation of a patient admitted to the emergency department due to HT crisis; should include a medical history, physical examination, and a series of diagnostic tests.

The drugs used in medical history should be questioned (such as the dose, range of use, abrupt discontinuation or switching to other treatment), sudden death, heart disease, or endocrine disorders in the family. Understanding this possible etiological factor provides important information. If the blood pressure is detected to be high during triage, the measurement should be repeated after the patient rests in a quiet environment for at least 5 minutes. Measurements should be made on both arms. A cuff of the appropriate size is required for the patient to be able to measure blood pressure accurately. According to the findings of the physical examination of the hypertensive emergency patient, it can be decided whether more tests are necessary. A diastolic decrescendo murmur heard on cardiac examination may tell aortic dissection. In this case, assessment of peripheral pulses and careful evaluation of blood pressures are required. Pulse pressure should also be evaluated. Patients thought to be significantly increased should be referred electively to a cardiologist because diastolic dysfunction can be seen in hypertensive patients with increased pulse pressure and high pulse pressure index ${ }^{9}$. In a comprehensive neurological examination, unrelated neurological deficits, seizures, confusion, delirium, and papilledema should suggest hypertensive encephalopathy. Pulmonary examination for the presence of hypertensive 
pulmonary edema should be performed and focus on evidence of rales, tachypnea or hypoxia. A murmur in the abdominal region should raise the suspicion of renal artery stenosis.

Diagnostic tests should be directed towards the system thought to be TOD. Chest pain is a common symptom in hypertensive emergencies. These patients should definitely be followed up by an electrocardiogram to be evaluated for ischemia and infarction. Cranial computed tomography should be performed primarily in any patient who is thought to have a stroke, seizure, or any neurological disorder due to a hypertensive emergency. If renal dysfunction is suspected, basic metabolic panel and urinalysis should be performed. Diagnostic tests should be tailored to focus on patient complaints and the end organ in question. The reason for this is both to maximize the efficiency of the emergency department and to minimize unnecessary investigations.

\section{Management}

The first step after the clinical evaluation of the patient is to determine if TOD is present. In a true hypertensive emergency, admission to the intensive care unit should be performed whenever possible, and intra-arterial pressure monitoring should be performed. This is because perfusion disorders may develop due to sudden and excessive blood pressure drops, which may cause target organ damage such as paralysis. In case of high blood pressure with signs of end-organ damage, emergency treatment with intravenous (I.V) agents should be applied because they are short-acting and easily titratable ${ }^{10,11}$. (Table 3).

Table 3: IV drugs that can be used in hypertensive emergencies ${ }^{12,13}$.

\begin{tabular}{|l|l|}
\hline Medication groups & Drugs \\
\hline Vasodilators & Nitroglycerin, Sodium Nitroprusside \\
\hline Calcium channel blockers & Nicardipine, Clevidipine \\
\hline Dopamine 1 agonist & \\
\hline Adrenergic blockers & Fenoldopam \\
\hline Other agents & \\
\hline
\end{tabular}

In treating many hypertensive emergencies, target blood pressure reduction is recommended by around $15 \%$ in the first hour and by a maximum of $25 \%$ within 2 hours. The proof of this situation is pheochromocytoma crisis and aortic dissection. In these two specific cases, the target blood pressure reduction should be greater than the specified rate. After this targeted acute reduction, blood pressure can be lowered more slowly, and drugs can be changed from the I.V to the orally. The choice of antihypertensive agents should be kept in mind in all cases, based on the type of end-organ damage, the pharmacokinetics of the drugs, and the patient's comorbidities.

Since there is no acute end-organ damage in hypertensive urgency, outpatient treatment is recommended for long-term treatment planning. Reduction of blood pressure to target values in treatment should be made within days.

\section{DISCUSSION}

Hypertensive crises constitute the majority of admissions to emergency services. Represents up to a quarter of all emergency department visits ${ }^{14}$. The presence or absence of TOD is a vital factor affecting the treatment process. Emergency departments need to identify hypertensive emergency quickly and differentiate it from hypertensive urgency and perform the appropriate intervention. Recognition of hypertensive urgency may cause concern among emergency physicians, which may lead to administering IV drugs. This approach may cause false hypotension and hypoperfusion in patients without end-organ damage. It has been shown that the approaches to asymptomatic HT of emergency department physicians who recently performed specialty training in the emergency department can approach the recommendations stated in the guidelines as the 
training period increases ${ }^{15}$. This shows how important trained health workers are in the approach to hypertension. It has been demonstrated that abrupt lowering of blood pressure in HT patients without TOD has no benefit in reducing short-term risk. In the clinical approach, the American College of Emergency Physicians did not recommend starting antihypertensive drugs in the emergency department for asymptomatic HT patients ${ }^{16}$. In contrast, hypertensive emergencies are closely associated with short- and long-term morbidity and mortality, with a 5-year mortality rate close to $100 \%{ }^{3}$.

A complete medical history, thorough physical examination, and appropriate laboratory and diagnostic screening are essential to identify individuals at risk. Because time is tissue in the hypertensive emergency, it should be given quickly once a drug is chosen. Since intensive care followup is required, patients should be managed in the intensive care unit. Hypertensive crises can be stopped and reversed with correct and rapid diagnosis and appropriate management.

\section{REFERENCES}

1. Stanaway JD et al. Global, regional, and national comparative risk assessment of 84 behavioural, environmental and occupational, and metabolic risks or clusters of risks for 195 countries and territories, 1990-2017: A systematic analysis for the Global Burden of Disease Stu. Lancet 392, 1923-1994 (2018)

2. Mills KT et al. Global Disparities of Hypertension Prevalence and Control: A Systematic Analysis of Population-Based Studies From 90 Countries. Circulation 134, 441-450 (2016).

3. Patel P, Ordunez P, Connell K, Lackland D, DiPette D; Standardized Hypertension Treatment and Prevention Network. Standardized Hypertension Management to Reduce Cardiovascular Disease Morbidity and Mortality Worldwide. South Med J. 2018;111(3):133-136. doi:10.14423/SMJ.0000000000000776

4. Salkic S, Batic-Mujanovic O, Ljuca F, Brkic $\mathrm{S}$. Clinical presentation of hypertensive crises in emergency medical services. Mater Sociomed. 2014;26(1):12-16. doi:10.5455/msm.2014.26.12-16

5. Williams B, Mancia G, Spiering W, et al. 2018 ESC/ESH Guidelines for the management of arterial hypertension: The Task Force for the management of arterial hypertension of the
European Society of Cardiology and the European Society of Hypertension: The Task Force for the management of arterial hypertension of the European Society of Cardiology and the European Society of Hypertension [published correction appears in J Hypertens. 2019 Jan;37(1):226]. $J$ Hypertens. 2018;36(10):1953-2041. doi:10.1097/HJH.0000000000001940

6. Astarita A, Covella M, Vallelonga F, et al. Hypertensive emergencies and urgencies in emergency departments: a systematic review and meta-analysis. $J$ Hypertens. 2020;38(7):1203-1210. doi:10.1097/HJH.0000000000002372

7. Kotchen TA. Historical trends and milestones in hypertension research: a model of the process of translational research. Hypertension. 2011;58(4):522-538. doi:10.1161/HYPERTENSIONAHA.111.177 766

8. Vallelonga F, Carbone F, Benedetto F, et al. Accuracy of a Symptom-Based Approach to Identify Hypertensive Emergencies in the Emergency Department. $J$ Clin Med. 2020;9(7):2201. Published 2020 Jul 12. doi:10.3390/jcm9072201

9. Ede H., Derya MA., Ardahanlı İ.,et al. HIPERTANSIF HASTALARDA NABIZ BASINCI ARALIĞI İLE SOL VENTRIKÜL DİASTOLIK FONKSIYYN ILIŞKİSI Association of Pulse Pressure Index with Left Ventricular Diastolic Function in Hypertensive Patients. Bozok Med J. 2015; 5(2), 24-30.

10. Brenner BM, Rector FC. Brenner \& Rector's the kidney. 10th edition. Philadelphia: Saunders Elsevier; 2016

11. Satheeshkumar A, Pena C, Nugent K. Current U.S. Guideline-Based Management Strategies for Special Clinical Situations Involving Hypertensive Crises: A Narrative Review of the Literature [published online ahead of print, 2020 Oct 19]. Cardiol Rev. 2020;10.1097/CRD.0000000000000364. doi:10.1097/CRD.0000000000000364

12. Chobanian AV, Bakris GL, Black HR, et al. Seventh report of the Joint National Committee on Prevention, Detection, Evaluation, and Treatment of High Blood Pressure. Hypertension. $\quad$ 2003;42(6):12061252.

doi:10.1161/01.HYP.0000107251.49515.c2 
13. Unger T, Borghi C, Charchar F, et al. 2020 International Society of Hypertension global hypertension practice guidelines. J Hypertens. 2020;38(6):982-1004. doi:10.1097/HJH.0000000000002453

14. Arbe G, Pastor I, Franco J. Diagnostic and therapeutic approach to the hypertensive crisis. Aproximación diagnóstica y terapéutica de las crisis hipertensivas. Med Clin (Barc). 2018;150(8):317-322. doi:10.1016/j.medcli.2017.09.027

15. Arıkan E, Arıkan N, Aktaş A, Ardahanlı İ . Asemptomatik Tansiyon Yüksekliğine Acil Tip Asistanlarının Yaklaşımının Değerlendirilmesi. Turkish Journal of Science and Health. (2021);2(2), 72-81. doi: $10.51972 /$ tfsd. 892363

16. O'Gara PT, Kushner FG, Ascheim DD, et al. 2013 ACCF/AHA guideline for the management of ST-elevation myocardial infarction: executive summary: a report of the American College of Cardiology Foundation/American Heart Association Task Force on Practice Guidelines: developed in collaboration with the American College of Emergency Physicians and Society for Cardiovascular Angiography and Interventions. Catheter Cardiovasc Interv. 2013;82(1):E1-E27. doi:10.1002/ccd.24776 